\title{
Efek Domino Performa Kelembagaan, Aspek Risiko, dan Pengembangan Usaha terhadap SDM Peternak Sapi Perah
}

\author{
Amam $^{1,2 *}$, P. A. Harsita ${ }^{1}$ \\ ${ }^{1}$ Program Studi Peternakan, Fakultas Pertanian, Universitas Jember 68121 \\ ${ }^{2}$ Program Studi Agribisnis, Fakultas Pertanian, Universitas Jember 68121 \\ Dikirim 27 September 2018 ; Diterima 15 November 2018
}

\begin{abstract}
ABSTRAK
Sumber Daya Manusia (SDM) peternak sapi perah merupakan individu yang bekerja sebagai penggerak usaha ternak sapi perah, sehingga sapi perah mempunyai kemampuan untuk memproduksi susu yang tinggi. Penelitian ini dilakukan di Kecamatan Pujon Kabupaten Malang pada bulan Juni - Agustus 2018 dengan tujuan: 1) merumuskan indikator performa kelembagaan, aspek risiko, dan pengembangan usaha yang mendukung SDM peternak sapi perah, dan 2) menemukan model SDM yang dipengaruhi oleh performa kelembagaan, aspek risiko, dan pengembangan usaha ternak sapi perah. Sampel penelitian sebanyak 105 peternak sapi perah. Variabel penelitian terdiri dari: performa kelembagaan $\left(\mathrm{X}_{1}\right)$, aspek risiko $\left(\mathrm{X}_{2}\right)$, pengembangan usaha $\left(\mathrm{X}_{3}\right)$, dan sumber daya manusia $\left(\mathrm{Y}_{1}\right)$. Data dianalisis menggunakan Structural Equation Model (SEM) dengan menggunakan aplikasi SmartPLS 2.0. Hasil penelitian menunjukkan bahwa: 1) terdapat indikator dari performa kelembagaan, aspek risiko, dan pengembangan usaha yang mendukung SDM peternak sapi perah; dan 2) SDM peternak sapi perah dipengaruhi oleh performa kelembagaan, aspek risiko, dan pengembangan usaha sebesar 16,4\%. Kesimpulan penelitian yaitu SDM peternak sapi perah secara positif dipengaruhi oleh performa kelembagaan $(0,213)$ dan aspek risiko $(0,108)$, sedangkan SDM peternak sapi perah secara negatif dipengaruhi oleh pengembangan usaha (-0.215).
\end{abstract}

Kata kunci: SDM, Sapi perah, kelembagaan, Risiko, Pengembangan usaha ternak

\section{Domino Effects of Institutional Performance, Risk Aspects, and Business Development on Dairy Farmer HR}

\begin{abstract}
Human Resources (HR) dairy farmers are individuals who work as movers of dairy cattle business, so that dairy cattle have the ability to produce high milk. This research was conducted in Pujon Subdistrict, Malang Regency in June - August 2018 with the aim of: 1) formulating indicators of institutional performance, risk aspects, and business development that support dairy farmer HR, and 2) finding HR models that was influenced by institutional performance, aspects risk, and the development of dairy cattle business. The research sample was 105 dairy farmers. Research variables consist of: institutional performance $\left(X_{1}\right)$, risk aspects $\left(X_{2}\right)$, business development $\left(X_{3}\right)$, and human resources $\left(Y_{1}\right)$. Data was analyzed by Structural Equation Model (SEM) using the SmartPLS 2.0 application. The results of the research show that: 1) there are indicators of institutional performance, risk aspects, and business development that support dairy farmers' HR; and 2) dairy farmers' human resources was affected by institutional performance, risk aspects, and business development by $16.4 \%$. The research conclusion is that dairy farmers' HR was positively influenced by institutional performance (0.213) and risk aspects (0.108), while dairy farmers' HR was negatively affected by business development (-0.215).
\end{abstract}

Keywords: HR, Dairy cattle, Institutional, Risk, Livestock business development

\section{PENDAHULUAN}

Kementerian Pertanian terus berupaya mendorong BUMN (Badan Usaha Milik Negara) dan swasta untuk menjalin kemitraan dengan peternak sapi perah melalui Program PKBL (Program Kemitraan Bina Lingkungan) dengan tujuan mendongkrak peningkatan populasi sapi perah dan produksi susu dalam negeri. Upaya tersebut salah satunya menghasilkan penandatanganan nota kesepahaman yang berorientasi pada peningkatan skala usaha ternak sapi perah antara PT Jasindo selaku BUMN dengan Koperasi Agro Niaga (KAN) di Jabung, Kabupaten Malang.

Pemerintah Indonesia sejatinya sudah banyak mencanangkan program-program untuk mendukung

\footnotetext{
*Penulis Korespondensi: Amam

Alamat: Jl. Kalimantan No. 37 Sumbersari, Jember 6812

E-mail: amam.faperta@unej.ac.id
}

pengembangan sapi perah nasional, seperti Program Kredit Usaha Rakyat (KUR), Kredit Usaha Pembibitan Sapi (KUPS), Upaya Khusus Sapi Indukan Wajib Bunting (Upsus Siwab), bantuan premi asuransi, fasilitas pengembangan investasi, dan programprogram kemitraan yang legal sesuai dengan regulasi Menteri Pertanian Republik Indonesia Tahun 2017 Nomor 13/PERMENTAN/PK.240/5/2017.

Ironisnya, fakta di lapangan menunjukkan bahwa banyak program pemerintah yang tidak tepat sasaran dan cenderung tidak berdampak pada kesejahteraan masyarakat. Hal tersebut diindikasikan terjadi karena SDM (Sumber Daya Manusia) peternak yang masih belum siap dan belum memadai. Tinggi dan rendahnya SDM peternak sapi perah berdasarkan hasil FGD (Focus Group Discussion) dengan para stakeholder pada bulan Juni 2018 di Kecamatan Pujon disebabkan oleh: a) performa kelembagaan peternak sapi perah, b) aspek risiko bisnis usaha ternak sapi perah yang 
mungkin diterima peternak, dan c) pengembangan usaha ternak sapi perah.

Peranan kelembagaan peternakan sangat dibutuhkan untuk mendukung pembangunan nasional, semakin baik peranan kelembagaan maka semakin tinggi kualitas SDM yang terbentuk, oleh sebab itu, penguatan kelembagaan memerlukan dukungan dari seluruh pihak (Wahyuni, 2017) karena merupakan salah satu amanat dari UU No. 19 tahun 2013 tentang Perlindungan dan Pemberdayaan Petani.

Aspek risiko bisnis usaha ternak sapi perah yang mungkin diterima peternak berdampak pada peningkatan kualitas SDM. Hal tersebut dicontohkan pada saat harga jual susu segar sangat rendah, peternak enggan menjual susu segar melainkan diolah dan diproses terlebih dahulu menjadi produk yang siap konsumsi seperti susu pasteurisasi.

Pengembangan usaha ternak sapi perah dinilai dapat meningkatkan SDM peternak sapi perah. Mardiana dan Irianto (2011) menyatakan bahwa salah satu wujud pengembangan usaha ialah meningkatnya adopsi teknologi, informasi, dan komunikasi. Adopsi teknologi pada level rendah menyebabkan peningkatan produktivitas, hal tersebut terjadi pada organisasi atau perusahaan dengan sumber daya yang melimpah (Ellitan, 2003), yang justru hal tersebut mungkin berdampak pada penurunan kualitas SDM peternak sapi perah ketika adopsi teknologi dilakukan pada level yang tinggi. SDM peternak sapi perah mempunyai peranan penting karena merupakan individu yang bekerja sebagai penggerak usaha ternak sapi perah, sehingga sapi perah mempunyai kemampuan untuk memproduksi susu yang tinggi.

Efek domino pada penelitian ini dimaksudkan untuk mengungkap dampak (impact) yang ditimbulkan dari pengaruh tiga variabel secara bersama-sama (performa kelembagaan, aspek risiko, dan pengembangan usaha ternak sapi perah) baik positif dan/atau negatif yang berkepanjangan dan berlangsung sangat cepat, sehingga mempunyai pengaruh terhadap SDM peternak sapi perah. Penelitian ini bertujuan untuk: 1) merumuskan indikator performa kelembagaan, aspek risiko, dan pengembangan usaha yang mendukung SDM peternak sapi perah, dan 2) menemukan model SDM yang dipengaruhi oleh performa kelembagaan, aspek risiko, dan pengembangan usaha ternak sapi perah.

\section{MATERI DAN METODE}

\section{Waktu dan Lokasi Penelitian}

Penelitian dilakukan pada bulan Juni sampai dengan Agustus 2018 di Kecamatan Pujon Kabupaten Malang. Kecamatan Pujon merupakan daerah dengan populasi sapi perah tebanyak di Jawa timur, yaitu *mencapai 20.670 ekor (BPS, 2017) yang terbagi menjadi 59 kelompok ternak (KOPSAE, 2017).

\section{Variabel Penelitian}

Penelitian terdiri dari 4 variabel utama dan 21 indikator. Variabel tersebut yaitu: a) performa kelembagaan, b) aspek risiko, c) pengembangan usaha, dan d) kualitas SDM peternak sapi perah. Model hubungan antar-variabel terdapat pada Gambar 1.

Tabel 1. Variabel dan Indikator Penelitian

\begin{tabular}{lc}
\hline \hline Performa Kelembagaan $\left(\mathrm{X}_{1}\right)$ & Notasi \\
\hline sarana kelompok peternak & $\mathrm{X}_{1.1}$ \\
capaian tujuan kelompok & $\mathrm{X}_{1.2}$ \\
fungsi dan tugas kelompok & $\mathrm{X}_{1.3}$ \\
struktur kelompok & $\mathrm{X}_{1.4}$ \\
kerukunan kelompok & $\mathrm{X}_{1.5}$ \\
bentuk kelembagaan kelompok & $\mathrm{X}_{1.6}$ \\
\hline Aspek Risiko $\left(\mathrm{X}_{2}\right)$ & Notasi \\
\hline Musim & $\mathrm{X}_{2.1}$ \\
Keamanan & $\mathrm{X}_{2.2}$ \\
Penyakit ternak & $\mathrm{X}_{2.3}$ \\
Flukatuasi harga susu & $\mathrm{X}_{2.4}$ \\
Kebijakan pemerintah & $\mathrm{X}_{2.5}$ \\
Kebijakan kelompok & $\mathrm{X}_{2.6}$ \\
Moralitas peternak & $\mathrm{X}_{2.7}$ \\
\hline Pengembangan Usaha $\left(\mathrm{X}_{3}\right)$ & $\mathrm{Notasi}$ \\
\hline Bertambahnya pendapatan & $\mathrm{X}_{3.1}$ \\
Bertambahnya populasi ternak & $\mathrm{X}_{3.2}$ \\
Bertambahnya tenaga kerja & $\mathrm{X}_{3.3}$ \\
Bertambahnya kandang & $\mathrm{X}_{3.4}$ \\
\hline Sumber Daya Manusia $\left(\mathrm{Y}_{1}\right)$ & $\mathrm{Notasi}$ \\
\hline Pengetahuan dan keterampilan & $\mathrm{Y}_{1.1}$ \\
peternak & \\
Status kesehatan peternak & $\mathrm{Y}_{1.2}$ \\
Motivasi peternak & $\mathrm{Y}_{1.3}$ \\
Kemampuan peternak dalam & $\mathrm{Y}_{1.4}$ \\
penggunaan bahasa sehari-hari & \\
\hline
\end{tabular}

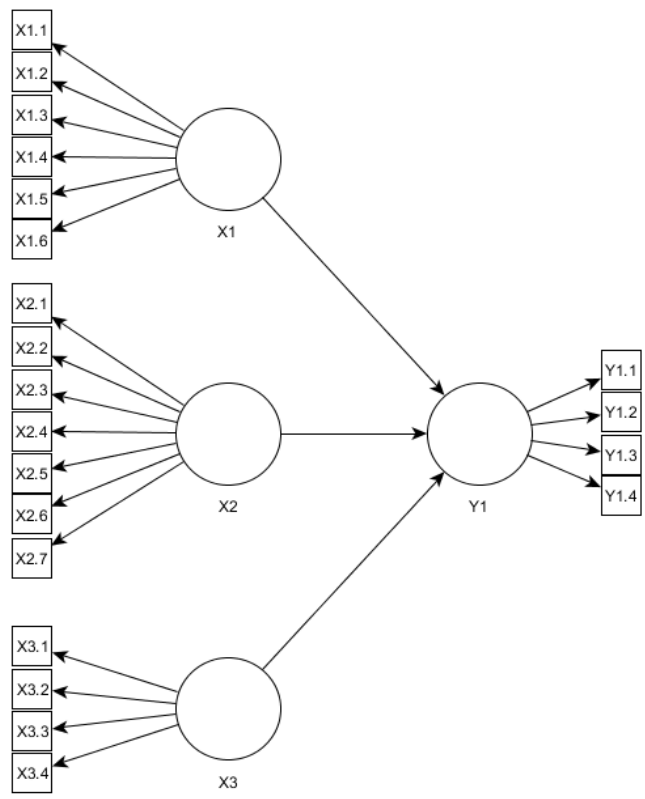

Gambar 1. Model Hubungan Variabel 
Penelitian terdiri dari 4 variabel utama dan 21 indikator. Variabel tersebut yaitu: a) performa kelembagaan, b) aspek risiko, c) pengembangan usaha, dan d) kualitas SDM peternak sapi perah.

\section{Populasi Penelitian}

Responden adalah peternak sapi perah di Kecamatan Pujon Kabupaten Malang. sampel dipilih secara purposive dengan perhitungan sampel berdasarkan teori Amora yaitu 5-10 kali jumlah variabel yang digunakan dalam penelitian. Jumlah sampel yang digunakan dalam penelitian ialah 21 variabel, sehingga besarnya sampel yang digunakan dalam penelitian yaitu:

$$
21 \text { variabel } X 5=105 \text { sampel }
$$

\section{Pengumpulan Data}

Data diperoleh langsung dari responden dengan menggunakan metode pengisian kuisioner dengan skala likert 1 sampai 5, metode wawancara, dan observasi untuk pengamatan langsung. Jenis data yang digunakan ialah data primer yang didapatkan dari peternak secara langsung dan data sekunder yang didapatkan dari sumber pendukung seperti BPS, KOPSAE, Kementerian Pertanian, dan Dinas Peternakan.

\section{Analisis Data}

Data dianalisis dengan teknik SEM (Strutural Equation Model) dengan menggunakan aplikasi SmartPLS 2.0. Hasil analisis tersebut digunakan untuk menjawab rumusan masalah pertama yaitu indikatorindikator yang berpengaruh terhadap SDM peternak sapi perah serta rumusan masalah kedua yaitu model SDM.

\section{HASIL DAN PEMBAHASAN}

\section{Uji Indikator}

Indikator pendukung variabel dalam penelitian ini diuji menggunakan SmartPLS 2.0. Indikator yang memenuhi syarat dan dinyatakan valid yaitu $>0.500$. Hasil uji indikator tersebut ditunjukkan pada Tabel 2 di bawah ini:

\section{Performa Kelembagaan}

Indikator dari performa kelembagaan yang berpengaruh terhadap SDM peternak sapi perah yang memenuhi syarat ialah adanya kerukunan antarpeternak sapi perah. Hermanto (2018) menyatakan bahwa penguatan kelembagaan merupakan salah satu upaya untuk menghadapi tantangan pertanian di masa depan dan Mukson et al. (2012) menyatakan bahwa lingkungan sosial, ekonomi, kelembagaan, dan lingkungan usaha perlu diperhatikan dalam upaya untuk meningkatkan produktivitas usaha dan pendapatan peternak, sehingga keberadaan kelembagaan petani sudah menjadi keniscayaan supaya memperbaiki taraf hidup, harkat, dan martabat petani Indonesia (Anantanyu, 2011). Performa kelembagaan di lokasi penelitian mampu memberikan motivasi, hal tersebut disebabkan karena adanya kerukunan antarpeternak di Kecamatan Pujon Kabupaten Malang.

\section{Aspek Risiko}

Indikator dari aspek risiko yang berpengaruh terhadap SDM peternak sapi perah yang memenuhi syarat ialah: a) flukatuasi harga susu, b) kebijakan pemerintah, c) kebijakan kelompok, dan d) moralitas peternak. Salah satu cara mengatasi fluktuasi harga

Tabel 2. Nilai Outer Loading

\begin{tabular}{|c|c|c|c|c|c|}
\hline & $\mathrm{X}_{1}$ & $\mathrm{X}_{2}$ & $\mathrm{X}_{3}$ & $Y_{1}$ & Result \\
\hline $\mathrm{X}_{1.1}$ & -.430 & & & & tidak \\
\hline $\mathrm{X}_{1.2}$ & -.675 & & & & tidak \\
\hline $\mathrm{X}_{1.3}$ & -.863 & & & & tidak \\
\hline $\mathrm{X}_{1.4}$ & -.584 & & & & tidak \\
\hline $\mathrm{X}_{1.5}$ & .730 & & & & valid \\
\hline $\mathrm{X}_{1.6}$ & -.236 & & & & tidak \\
\hline $\mathrm{X}_{2.1}$ & & -.237 & & & tidak \\
\hline $\mathrm{X}_{2.2}$ & & -.011 & & & tidak \\
\hline $\mathrm{X}_{2.3}$ & & -.522 & & & tidak \\
\hline $\mathrm{X}_{2.4}$ & & .626 & & & valid \\
\hline $\mathrm{X}_{2.5}$ & & .747 & & & valid \\
\hline $\mathrm{X}_{2.6}$ & & .874 & & & valid \\
\hline $\mathrm{X}_{2.7}$ & & .798 & & & valid \\
\hline $\mathrm{X}_{3.1}$ & & & .080 & & tidak \\
\hline$X_{3.2}$ & & & .308 & & tidak \\
\hline $\mathrm{X}_{3.3}$ & & & .831 & & valid \\
\hline $\mathrm{X}_{3.4}$ & & & .639 & & valid \\
\hline$Y_{1.1}$ & & & & .433 & tidak \\
\hline $\mathrm{Y}_{1.2}$ & & & & .771 & valid \\
\hline$Y_{1.3}$ & & & & .836 & valid \\
\hline$Y_{1.4}$ & & & & -.037 & tidak \\
\hline
\end{tabular}

Sumber: Data diolah (2018) 
susu diantaranya yaitu: 1) meningkatkan posisi tawar peternak (Nasrul, 2012) dengan melakukan pengolahan susu segar menjadi produk yang siap konsumsi, 2) menggunakan sistem integrasi tanaman-ternak (Tawaf et al., 2016), 3) melakukan pembibitan sendiri sebagai langkah investasi awal (Perilla et al., 2009). Aspek risiko bisnis di lokasi penelitian mampu memberikan motivasi, hal tersebut disebabkan karena fluktuasi harga susu, kebijakan pemerintah, kebijakan kelompok, dan moralitas peternak mendukung peningkatan kualitas SDM.

Fluktuasi harga susu yang diterima peternak berdampak pada motivasi peternak untuk mengolah susu segar menjadi susu siap konsumsi sehingga meningkatkan nilai tambah peternak di Kecamatan Pujon Kabupaten Malang. Pengolahan susu segar menjadi susu siap konsumsi juga didukung oleh kebijakan pemerintah dan kebijakan kelompok supaya peternak mandiri dan sejahtera.

\section{Pengembangan Usaha}

Indikator pengembangan usaha yang berpengaruh terhadap SDM peternak sapi perah ialah: a) bertambahnya pendapatan peternak, b) bertambahnya tenaga kerja, dan c) bertambahnya kandang. Keputusan petani untuk untuk meningkatkan skala usaha ternaknya dipengaruhi secara positif signifikan oleh tingkat keterlibatan tenaga kerja keluarga dan harapan peternak (Roessali et al., 2011) dan keterampilan tenaga kerja yang disertai motivasi, berpengaruh nyata terhadap produktivitas usaha (Riszqina et al., 2014) sehingga peternak perlu melakukan efisiensi biaya produksi seperti penggunaan pakan dan obat-obatan (Pakage et al., 2015).

Pengembangan usaha di lokasi penelitian yang meliputi bertambahnya pendapatan, bertambahnya tenaga kerja, dan bertambahnya kandang berdampak pada penurunan motivasi peternak. Semakin besar investasi yang peternak keluarkan untuk usaha ternak sapi perah, maka semakin besar juga risiko kegagalan bisnis yang mungkin peternak terima.

\section{Sumber Daya Manusia}

Indikator SDM peternak sapi perah yang dipengaruhi oleh performa kelembagaan, aspek risiko, dan pengembangan usaha ialah: a) status kesehatan peternak, dan b) motivasi peternak. Riszqina et al. (2014) menyatakan bahwa keterampilan dan motivasi berpengaruh nyata terhadap produktivitas usaha ternak. SDM merupakan salah satu instrumen penting bagi organisasi dalam mencapai berbagai tujuannya (Irianto, 2011), maka dari itu kegagalan mengelola SMD dapat mengakibatkan timbulnya gangguan dalam pencapaian tujuan organisasi (Riyadi, 2012).

Peternak sapi perah mempunyai motivasi untuk terus melangsungkan usaha ternaknya. Motivasi tersebut timbul karena status kesehatan peternak yang masih mampu melakukan usaha ternak, sedangkan peternak yang mengalami gangguan kesehatan di lokasi penelitian cenderung menjual ternaknya atau menitipkan ternaknya untuk kemudian dilakukan kerjasama bagi hasil (profit sharing).

\section{Uji Struktural}

Analisis SEM dengan SmartPLS 2.0 menghasilkan kriteria uji struktural berupa Composite Reliability (CR), nilai R Square (R2), dan nilai Cronbach's Alpha (CA), masing-masing nilai tersebut didapatkan hasil pada Tabel 3 di bawah ini:

Tabel 3. Uji Struktural

\begin{tabular}{clll}
\hline \hline & $\mathrm{CR}$ & $\mathrm{R}^{2}$ & $\mathrm{CA}$ \\
\hline $\mathrm{X}_{1}$ & 0.535 & & 0.553 \\
$\mathrm{X}_{2}$ & 0.545 & & 0.599 \\
$\mathrm{X}_{3}$ & 0.552 & & 0.564 \\
$\mathrm{Y}_{1}$ & 0.615 & 0.204 & 0.573 \\
\hline Sumber:
\end{tabular}

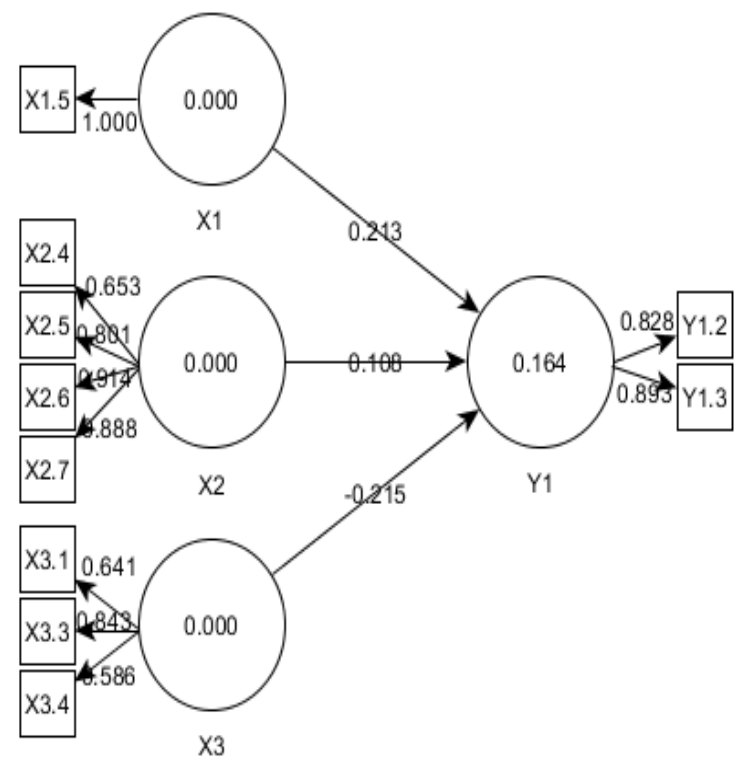

Gambar 2. Hasil Logaritma PLS

Uji struktural pada uji pengaruh atau uji hipotesis pada Gambar 2 dilakukan setelah uji indikator yang terdiri dari nilai koefisien determinasi (R2), t-statistik, dan koefisien parameter. Hasil uji dengan analisis SEM didapatkan hasil sebagai berikut:

Tabel 4. Uji Model

\begin{tabular}{ll}
\hline \hline $\begin{array}{l}\text { Pengujian } \\
\text { Koefisien Determinasi } \mathrm{R}^{2}\end{array}$ & Hasil Uji \\
\hline Sumber Daya Manusia & 0.164 \\
\hline $\mathrm{T}$-statistik & \\
\hline $\mathrm{X}_{1} \rightarrow \mathrm{Y}_{1}$ & 1.971 \\
$\mathrm{X}_{2} \rightarrow \mathrm{Y}_{1}$ & 0.872 \\
$\mathrm{X}_{3} \rightarrow \mathrm{Y}_{1}$ & 1.423 \\
\hline Koefisien Parameter & \\
\hline $\mathrm{X}_{1} \rightarrow \mathrm{Y}_{1}$ & 0.213 \\
$\mathrm{X}_{2} \rightarrow \mathrm{Y}_{1}$ & 0.108 \\
$\mathrm{X}_{3} \rightarrow \mathrm{Y}_{1}$ & -0.215 \\
\hline
\end{tabular}




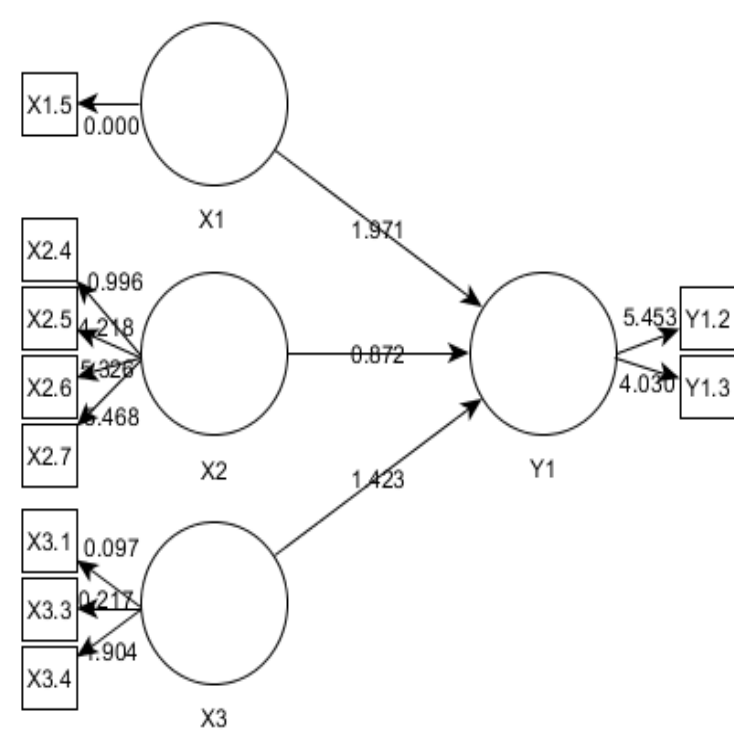

Gambar 3. Hasil Bootstraping PLS

\section{Dampak Performa Kelembagaan}

Performa kelembagaan berpengaruh terhadap SDM peternak sapi perah pada Gambar 3 sebesar 1.971, artinya terdapat pengaruh positif dari performa kelembagaan terhadap SDM peternak sapi perah. Semakin besar performa kelembagaan maka semakin tinggi SDM peternak sapi perah.

Peranan kelompok tani untuk mendukung SDM perlu ditingkatkan, sebab salah satu tujuannya adalah untuk memfasilitasi penyediaan kredit bagi peternak dan mengatur perdagangan pakan ternak (Kalangi et al., 2014), sehingga dinamika kelompok tani yang baik, terlihat dari kuatnya faktor-faktor kekuaatan yang mampu menggerakkan perilaku anggota kelompok untuk mencapai tujuan secara efektif dan efisien (Suswandi dan Sutarno, 2017).

Dampak performa kelembagaan terhadap SDM peternak di lokasi penelitian adalah kerukunan sesama anggota. Langkah kelembagaan untuk terus mengupayakan kerukunan sesama peternak adalah dengan cara melakukan pertemuan rutin, sehingga bermanfaat untuk memecahkan permasalahan bersama yang berorientasi pada kesejahteraan peternak sapi perah.

\section{Dampak Aspek Risiko}

Aspek risiko berpengaruh terhadap SDM peternak sapi perah sebesar 0.108 , artinya terdapat pengaruh positif dari aspek risiko terhadap SDM peternak sapi perah. Semakin besar aspek risiko maka semakin tinggi SDM peternak sapi perah.

Aspek risiko seperti pembibitan, sanitasi, perawatan kesehatan ternak, dan manajemen pemberian pakan harus diperhatikan sehingga tidak menghambat pengembangan usaha (Septiani et al., 2017), sehingga faktor kepemilikan ternak dan curahan tenaga kerja turut berpengaruh terhadap pendapatan peternak (Taslim, 2011).
Dampak aspek risiko terhadap SDM peternak di lokasi penelitian adalah fluktuasi harga susu, kebijakan pemerintah, kebijakan kelembagaan, dan moralitas peternak. Langkah peternak untuk mengatasi fluktuasi harga susu dilakukan dengan cara mengolah susu segar menjadi susu siap konsumsi. Pengolahan susu menjadi produk siap saji juga didukung oleh kebijakan pemerintah dan kebijakan kelembagaan. Moralitas peternak sapi perah mendukung dilakukannya pengolahan susu segar karena dinilai dapat meningkatkan nilai tambah (nilai jual) produk susu.

\section{Dampak Pengembangan Usaha}

Pengembangan usaha berpengaruh terhadap SDM peternak sapi perah sebesar -0.215 , artinya terdapat pengaruh negatif dari aspek pengembangan usaha terhadap SDM peternak sapi perah. Semakin besar pengembangan usaha maka semakin rendah SDM peternak sapi perah. Program pengembangan usaha ternak sapi perah bukan hanya tanggung jawab pemerintah, melainkan semua stakeholder yang ikut berperan dalam pengambilan keuntungan dari usaha ternak sapi perah.

Santosa dan Wulandari (2013) menyatakan bahwa potensi-potensi daerah untuk pengembangan sapi perah dapat ditingkatkan dengan penyediaan ketersediaan pakan, pengetahuan peternak, permintaan susu, pendapatan peternak, infrastruktur pasar, peranan lembaga pemberi kredit dan kebijakan pemerintah lokal, sedangkan Elida (2016) menambahkan bahwa sumber daya yang mendukung usaha ternak sapi perah dinataranya yaitu tenaga kerja keluarga, motivasi peternak, serta tersedianya pakan dan obat-obatan.

Curahan tenaga kerja dan jumlah kepemilikan ternak berpengaruh terhadap pendapatan peternak, dan jumlah kepemilikan ternak merupakan faktor dominan yang paling berpengaruh terhadap pendapatan peternak (Taslim, 2011).

Dampak pengembangan usaha terhadap SDM peternak di lokasi penelitian adalah bertambahnya pendapatan, bertambahnya tenaga kerja, dan bertambahnya kandang. Dampak tersebut berpengaruh secara negatif terhadap SDM peternak sapi perah. Artinya, semakin besar investasi yang peternak keluarkan untuk usaha ternak sapi perah maka semakin besar juga risiko bisnis yang mungkin peternak terima, sehingga dampak pengembangan usaha di lokasi penelitian dapat menurunkan motivasi peternak.

\section{Efek Domino Performa Kelembagaan, Aspek Risiko, dan Pengembangan Usaha terhadap SDM Peternak Sapi Perah}

SDM peternak sapi perah dipengaruhi oleh performa kelembagaan, aspek risiko, dan pengembangan usaha sebesar $16,4 \%$, sedangkan sisanya sebanyak $83,6 \%$ dipengaruhi oleh faktor lain yang tidak terdapat di dalam penelitian.

Susilawati (2013) menyatakan bahwa budaya organisasi sangat dominan pengaruhnya terhadap perilaku SDM di suatu orgnasasi (lembaga), sehingga 
mengakibatkan perlunya adanya pengelolaan dan pengembangan SDM di dalam suatu organisasi (Limawandoyo dan Simanjutak, 2013) seperti dicontohkan Suryana (2009) misalkan melakukan usaha ternak dengan sistem kemitraan bisnis. Kemitraan merupakan kegiatan kerja sama antarpelaku agribisnis mulai dari tingkat praproduksi, produksi hingga pemasaran, yang dilandasi azas saling membutuhkan dan menguntungkan diantara pihakpihak yang bekerja sama, dalam hal ini perusahaan dan peternak untuk saling berbagi biaya, risiko, dan manfaat.

Konsep kemitraan bisnis juga nanti bisa diarahkan pada sistem integrasi ternak-tanaman (Elly et al., 2008), dengan tujuan dapat meningkatkan pendapatan petani maupun pemerintah, memperbaiki kesuburan tanah, menyediakan sekaligus meningkatkan produktivitas pakan, selain sebagai sumber pendapatan tambahan melalui penjualan pupuk kompos dan penyewaan tenaga kerja ternak. Pengembangan usaha ternak dapat dilakukan dengan memberdayakan sumber daya lokal. Keberhasilan pengembangan usaha taniternak antara lain ditentukan oleh kerja sama antara petani/peternak dan pemerintah melalui pendekatan kelompok atau kelembagaan yang berorientasi pada pengembangan usaha dengan memperhatikan aspek risiko usaha ternak, sehingga diharapkan mampu meningkatkan SDM peternak sapi perah untuk mendukung pembangunan pertanian secara berkelanjutan.

\section{KESIMPULAN}

1. Indikator-indikator yang berpengaruh terhadap SDM peternak sapi perah ialah: a) variabel performa kelembagaan terdiri dari kerukunan kelompok peternak; b) variabel aspek risiko terdiri dari fluktuasi harga susu, kebijakan pemerintah, kebijakan kelompok, dan moralitas peternak; c) variabel pengembangan usaha terdiri dari bertambahnya pendapatan peternak, bertambahnya tenaga kerja, dan bertambahnya kandang; sedangkan indikator SDM peternak yaitu status kesehatan peternak dan motivasi peternak.

2. SDM peternak sapi perah dipengaruhi oleh performa kelembagaan, aspek risiko, dan pengembangan usaha sebesar 16,4\%. SDM peternak sapi perah dipengaruhi oleh: a) performa kelembagaan sebesar 0.213 , b) aspek risiko bisnis sebesar 0.108 , dan c) pengembangan usaha sebesar -0.215 .

\section{UCAPAN TERIMA KASIH}

Peneliti mengucapkan terimakasih banyak kepada para stakeholder khususnya peternak sapi perah di Kecamatan Pujon Kabupaten Malang yang sudah berpartisipasi di acara FGD (Focus Group Discussion) dan bersedia menjadi responden (narasumber) dalam proses pengambilan data penelitian. Peneliti juga mengucapkan terimakasih kepada LP2M (Lembaga Penelitian dan Pengabdian kepada Masyarakat) Universitas Jember (UNEJ) yang sudah mewadahi proses pelaksanaan penelitian.

\section{DAFTAR PUSTAKA}

Anantanyu, S. 2011. Kelembagaan Petani: Peran dan Strategi Pengembangan Kapasitasnya. Jurnal SEPA 7(2) : 102-109.

Elida, S. 2016. Potensi dan Strategi Pengembangan Usaha Ternak Sapi Perah di Kecamatan Pangkalan Kerinci Kabupaten Pelalawan. Gontor Agrotech Science Journal 2(2): 53-70.

Elly, F. M., B. M. Sinaga, S. U. Kuntjoro, dan N. Kusnadi. 2008. Pengembangan Usaha Ternak Sapi Rakyat Melalui Integrasi Sapi-Tanaman di Sulawesi Utara. Jurnal Litbang Pertanian 27(2): 63-68.

Hermanto. 2018. Pengentasan Kemiskinan di Perdesaan: Pengembangan SDM, Penguatan Usaha, dan Inovasi Pertanian. Forum Penelitian Agro Ekonomi 35(2): 139-150.

Irianto, J. 2011. Manajemen Sumber Daya Manusia Sektor Publik di Indonesia: Pengantar Pengembangan Model SMDM Sektor Publik 24(4): 281-291.

Limawandoyo, E. A. dan A. Simanjutak. 2013. Pengelolaan dan Pengembangan Sumber Daya Manusia pada PT. Aneka Sejahtera Engineering. Jurnal Manajemen Bisnis Petra 1(2): 1-12.

Mardiana, Yohanes G. B., dan B. Irianto. 2011. Peran kelembagaan pertanian dalam penyebaran inovasi teknologi produksi benih kedelai di Nusa Tenggara Barat. Prosiding Seminar Hasil Penelitian Tanaman Aneka Kacang dan Umbi. Nusa Tenggara Barat (NTB), Indonesia. pp. 428437.

Mukson, M. Isbandi, S. I. Santosa, Sudjadmogo, A. Setiadi. 2012. Analysis of Various Factors in Order to Enhance Productivity and Income of Diary Cattle Farmers in Central Java, Indonesia. Journal of The Indonesian Tropical Animal Agriculture 37(3): 220-208.

Nasrul, W. 2012. Pengembangan Kelembagaan Pertanian untuk Meningkatkan Kapasitas Petani terhadap Pembangunan Pertanian. Jurnal Menara Ilmu 3(29): 166-174.

Pakage, S., B. Hartono, Z. Fanani, B. A. Nugroho. 2015. Analysis of Technical, Allocative and Economic Efficiency of Broiler Production Using Closed House System in Malang District of East Java, Indonesia. Livestock Research for Rural Development 27(9): 1-8.

Perilla, M. V., J. M. Escala and A. Setiadi. 2009. A Case Study of Luntian Multi-purpose Cooperative in Barangay Lalaig, Tiaong, Quezon, Philippines: A Vertical Integration Approach. Journal of The Indonesian Tropical Animal Agriculture 34(3): 216-223. 
Riszquna, Isbandi, E. Rianto and S. I. Santoso. 2014. The Analysis of Factors Affecting The Performance in Benefits of Karapan (Racing) Cattle Business in Madura Island, East Java. Journal of The Indonesian Tropical Animal Agriculture 39(1): 65-72.

Riyadi. 2012. Faktor Sumber Daya Manusia yang Meningkatkan Kinerja Karyawan dan Perusahaan di Kalbar. Jurnal Eksos 8(2): 114-119.

Roessali, W., Masyhuri, S. Nurtini, D. H. Darwanto. 2011. Factors Influencing Farmers Decision to Increase Beef Cattle Business Scale in Central Java Province. Journal of The Indonesian Tropical Animal Agriculture 36(1): 27-35.

Santosa, S. I., A. Setiadi dan R. Wulandari. 2013. Analisis Potensi Pengembangan Usaha Peternakan Sapi Perah dengan Menggunakan Paradigma Agribisnis di Kecamatan Musuk Kabupaten Boyolali. Buletin Peternakan 37(2): 125-135.

Septiani, W., Marimin, Y. Herdiyeni and L. Haditjaroko. 2017. Risk Based Milk Pricing Model at Diary Farmers Level. Media Peternakan 40(3): 218-227.

Suryana. 2009. Pengembangan Usaha Ternak Sapi Potong Berorientasi Agribisnis dengan Pola Kemitraan. Jurnal Litbang Pertanian 28(1): 29-37.

Susilowati, Y. 2013. Jurnal Manajemen Teknologi. Pengaruh Aspek Pengelolaan Sumber Daya Manusia terhadap Peningkatan Kinerja Organisasi di Industri Otomotif di Indonesia 12(1): 1-19.

Suswandi dan Sutarno. 2017. Analisa Dinamika dan Kemandirian Kelembagaan Ekonomi Petani dengan Penerapan Pertanian Organik Bersertifikasi di Kabupaten Boyolali. Prosiding Seminar Nasional. pp. 220-240.

Taslim. 2011. Pengaruh Faktor Produksi Susu Usaha Ternak Sapi Perah Melalui Pendekatan Analisis Jalur di Jawa Barat. Jurnal Ilmu Ternak 10(1): 5256.

Tawaf, R., M. Paturochman, R. Herlina, M. Sulistiyati and A. Fitriani. 2016. The Optimation of Farmers Familities Revenue The Integration of Pasundan Cattle and Paddy Farming in West Java. Journal of The Indonesian Tropical Animal Agriculture 42(4): 270-278.

Wahyuni, D. 2017. Penguatan Kelembagaan Petani Menuju Kesejahteraan Petani. Jurnal Kesejahteraan Sosial 10 (17): 9-12.

Wiyono, G. 2011. Merancang Penelitian Bisnis dengan Alat Analisis SPSS 17.0 \& Smart PLS 2.0. Penerbit: Unit Penerbit dan Percetakan STIM YKPN Yogyakarta. Yogyakarta. 